() С. Б. Фіялка, канд. наук із соц. комунікацій, доц., КП। ім. Ігоря Сікорського, Київ, Україна

\title{
ЗАСОБИ ПІДВИЩЕННЯ ЦИТОВАНОСТІ НАУКОВИХ ПУБЛІКАЦІЙ
}

Статистика цитувань наукових публікацій відображає визнання оприлюднених наукових ідей, їх вплив на дослідження інших учених та практичну цінність наукових результатів. Як індикатор якості статті цитування важливе для окремого вченого, наукового колективу, установи і країни в цілому. У пропонованій статті на емпіричному матеріалі узагальнено рекомендації щодо підвищення рівня цитування наукових публікацій.

Ключові слова: цитованість; кількість цитувань; науковий журнал; наукометрична база; відкритий доступ; оприлюднення наукових результатів.

\section{Постановка проблеми}

Кількість цитувань наукових статей широко використовується в академічному середовищі. Цитування відображає визнання оприлюднених наукових ідей, їх вплив на дослідження інших науковців та практичну цінність результатів досліджень, викладених у статтях [1]. Пік цитованості наукової статті припадає на 2-4 роки після опублікування [2].

Як індикатор якості статті цитування важливе не лише для автора, а й для закладу, який він представляє [3]. Рівнем цитування визначається також місце в науковому співтоваристві країни походження авторів статті [4]. Крім того, кількість цитувань може використовуватися під час ухвалення рішень щодо фінансування досліджень [5]. Тож інтеграція української науки у світовий академічний простір, зокрема через підвищення рівня цитованості праць вітчизняних дослідників, стає дедалі актуальнішою.

\section{Аналіз попередніх досліджень}

А. Гван, Дж. Арбау, Р. Бенто та ін., дослідивши 596 статей із семи провідних журналів у сфері бізнесу, виявили чинники, що впливають на цитування наукових праць. Провідне місце серед них належить кількості посилань на інші наукові роботи. Тобто названі дослідники довели, що вищі шанси зацікавити читачів мають публікації, які містять істотне теоретичне підґрунтя [6] .

М. Елгенді дослідив характеристики статей з високою та низькою цитованістю (кількість переглядів, символів, рисунків, таблиць, рівнянь, кількість авторів, довжина заголовка). При цьому науковець брав статті різних

(c) 2019 p. 
типів з різних дисциплін та не прив'язувався до імпакт-фактора видання. Було встановлено прямо пропорційну залежність між кількістю цитувань і різноманіттям авторів, а також кількістю переглядів, кількістю рисунків і таблиць. Цікаво, що кількість цитувань виявилася обернено пропорційною до довжини заголовка, а кількість наявних у тексті статті рівнянь не вплинула на кількість цитувань [7]. Крім того, було встановлено прямо пропорційний взаємозв'язок між довжиною статті та її цитованіСтю [8].

У цілому, порівняно з узагалі нецитованими статтями, часто цитовані статті мають у 3-5 разів більшу кількість авторів, та у 2,5-3,5 раза більший обсяг [9].

у 2015 р. А. Летчфорд, Г. Моат і Т. Прейс виявили, що частіше цитують статті з коротшими заголовками, оскільки вони простіші для розуміння. Проте науковці не вказали, скільки саме слів визначають заголовок як довгий чи короткий [10]. Р. Мертон з'ясував, що частіше цитують науковців, які мають високі посади [11].

А. ван Раєн, використовуючи бібліометричний підхід, дослідив феномен «сплячої красуні» (sleeping beauty) у науці, коли публікації, не помічені іншими науковцями впродовж тривалого часу, раптом привертають увагу. Дослідник розглянув три основні змінні: 1) «глибина сну» (якщо стаття отримує щонайменше одне цитування в середньому на рік, ідеться про «глибокий сон», якщо від одного до двох, «менш глибокий сон»); 2) «тривалість сну», 3) «інтенсивність пробудження» (кількість цитувань на рік протягом чотирьох років після «сну»). Імовірність «пробудження» після «глибокого сну» тим менша, чим тривалішим був «сон». Коли йдеться про «менш глибокий сон», то тривалість періоду «сну» менше впливає на ймовірність «пробудження» [12].

П. Болл вважає цитованість справою щасливого випадку, оскільки іноді важлива наукова робота може лишитися непоміченою за життя автора й навіть після його смерті [13].

М. Бітетті та Дж. Феррарес протестували гіпотезу, що науковці, які не $є$ носіями англійської мови, схильні вважати, що опублікування статті англійською зробить їхні статті більш помітними й цитованими. Дослідники порівняли вплив мови на кількість цитувань статей, опублікованих у шести журналах із природничих наук представниками п'яти країн. Статті англійською мали вищу цитованість. Це пояснюється тим, що такі статті доступні для більшої аудиторії, оскільки саме англійська $€$ мовою міжнародного наукового спілкування. Однак науковці визнають, що використання цієї мови може негативно позначатися на поширенні наукового знання всередині неангломовних країн [14].

\section{Мета роботи}

Узагальнити рекомендації щодо підвищення рівня цитованості наукових публікацій.

\section{Результати проведених досліджень}

Наукова продуктивність ученого характеризується кумулятивним індексом цитування. Ідеться про загальну кількість 
посилань на всі роботи автора за час його діяльності. Намагаючись підвищити свій індекс цитування, кожен науковець вирішує, де саме опублікуватися та як зробити так, щоб публікація стала доступною та потрібною для якомога більшої кількості теоретиків і практиків зі своєї й суміжних галузей.

Щоб з'ясувати характеристики активно цитованих статей, нами було переглянуто Journal Citation Reports компанії Clarivate Analytics за 2019 р., де наведено дані про цитування науковою спільнотою журналів, включених в індекси Science Citation Index Expanded (SCIE) i Social Sciences Citation Index (SSCI) Web of Science Core Collection. Journal Citation Reports інтегровані в пошукову платформу Web of Science. Відтак методом випадкового відбору було відібрано 100 статей, які мають 50 і більше цитувань за два останні роки, з різних журналів.

Відтак вдалося виокремити такі характеристики, притаманні часто цитованим науковим публікаціям.

Оглядовий характер статей. У процесі дослідження виявлено, що $73 \%$ статей мають оглядовий характер. Такі статті є результатом аналітико-синтетичного опрацювання великого масиву наукової інформації та містять від 30 до 94 посилань. Безпосередній зв'язок між кількістю цитувань статті та кількістю наявних у ній посилань доводять також Г. Вебстер, П. Джонасон та Т. Щембер [15]. Саме бібліографічні посилання $€$ своєрідним індикатором зв'язків між науковими публікаціями та їх авторами, критерієм внеску окремих науковців, установ і країн у науку.
Розміщення у виданнях відкритого доступу. 62 \% аналізованих статей розміщено у виданнях відкритого доступу. Такі статті читають і цитують частіше, оскільки зникає фінансовий бар'єр у вигляді передплати [16].

Наявність загальних слів у заголовках. У заголовках проаналізованих статей з високим рівнем цитованості виявлено загальні слова, які траплялися із частотністю понад п'ять разів: огляд (review), моніторинг (monitoring), ефект (effect), метод (method), теорія (theory), аналіз (analysis), застосування (applications), вивчення (learning), дослідження (study). Принагідно зауважимо, що формулювання заголовка статті у вигляді запитання негативно впливає на цитованість публікації [17].

Співавторство. Отримані нами дані підтверджують наукові результати С. Вутчі, Б. Джонса та Б. Уззі, котрі, проаналізувавши 19,9 млн статей за 50 років, виявили, що статті в співавторстві цитуються частіше [18]. 84 проаналізовані нами статті мають п'ять і більше авторів. Міжнародна співпраця теж значною мірою впливає на цитованість. Наше дослідження засвідчує, що статті, опубліковані в міжнародному співавторстві, цитуються втричі частіше, ніж написані науковцями $з$ однієї держави.

Наявність таблиць і рисунків. 79 статей містять таблиці та (або) рисунки. Вони можуть розміщуватися як у самому тексті, так і наприкінці статті та допомагають структурувати інформацію й утримати увагу читача.

Перелічені вище характеристики не $є$ достатньою умовою 
для цитування публікації. Статті цитують передусім завдяки їхній науковій цінності. Проте опублікування якісної статті - це лише половина шляху до того, щоб публікацію процитували в майбутньому. Решта шляху - це рекламування та поширення публікації [19]. Щоб подолати цей шлях, доцільно поділитися публікацією з авторами, яких процитовано в статті, а також практиками, яким стаття може бути корисною.

Доречно також розмістити інформацію щодо статті в професійних групах у соціальних мережах. Щоб зробити статтю більш доступною для широкої аудиторії, слід скористатися ORCID, ResearchGate, Mendeley. Окремої уваги заслуговує сервіс Kudos, який підвищує видимість наукових результатів. Цей ресурс дає змогу структурувати інформацію про статтю так, щоб вона була зрозумілою не лише колегам, а й могла зацікавити фахівців у сфері бізнесу, промисловості, наукових журналістів. Опис статті Kudos складається з рубрик: «Про що стаття?», «Чому це важливо?» та «Перспективи». Також завдяки ресурсу в користувача є можливість відстежувати статистику: кількість переглядів, завантажень, постів у соцмережах (Twitter, Linkedln, Facebook), цитувань у Web of Science.

Поліпшити видимість статті для наукової спільноти може також оприлюднення наукових результатів на конференціях, симпозіумах, семінарах, круглих столах тощо [20].

Важливо також подбати про пошукову оптимізацію публікації. Зокрема, вибирати ключові сло- ва, за якими дослідники потенційно можуть будувати свої пошукові запити. Однак якщо в багатьох статтях використовуються ті самі ключові слова, це може ускладнювати пошук саме цієї статті. Тому поряд із загальноприйнятими в галузі доцільно використовувати більш спеціалізовані ключові слова.

Істотну роль для пошукової оптимізації відіграє тип графіки, яку використовує автор статті. Якщо застосовують розширення .tiff, .bmp, .jpeg, .png, .pdf, .gif and .psd тощо, текст у такій графіці не ідентифікується пошуковиками. Тому варто використовувати векторну графіку (розширення .svg, .ai, .eps, .ps), ключові слова в якій пошукові системи враховують під час обробки запиту користувача.

Насамкінець варто наголосити, що ми не погоджуємося з думкою М. Гріффітса, що чим більше автор пише й публікує, тим вища ймовірність цитування [21].

\section{Висновки}

Підвищення цитованості не має бути самоціллю, на першому місці має бути наукова цінність, новизна самого дослідження та академічна репутація окремого вченого, наукового колективу, установи та країни в цілому. Статті цитують тоді, коли вони представляють наукові результати, які мають важливе теоретичне та (або) практичне значення. Однак при цьому важливий добір ключових слів, тип графіки, що його використовує автор статті, кількість та актуальність цитованих джерел. Поліпшити видимість публікації можна завдяки 
розміщенню інформації щодо статті в професійних групах у соціальних мережах, а також використанню сервісу Kudos. Натомість на заваді цитованості можуть стати інформаційний шум, відсутність доступу до публікації, мовний бар'єр, низький рівень видання (відсутність рецензування, непрозора фінансова політика тощо).
Варто зважати, що існують також і інші індикатори, які $є$ альтернативою кількості цитувань наукових статей. Ідеться, зокрема, про цитування патентів як показник комерційної цінності, цитування в соціальних мережах як свідчення інтересу наукової громадськості та згадування в списках рекомендованих джерел до навчальних курсів.

\section{Список використаної літератури/References}

1. Garfield, E. \& Small, H. (1978). Citation Data as Science Indicators. Toward a Metric of Science. New York: John Wiley \& Sons, 1978, 181-182 [in English].

2. Amin, M. \& Mabe, M. (2003). Impact factors: use and abuse. Journal of Medicina, 63, 347-354 [in English].

3. Jones, K. \& Evans, K. (2013). Good Practices for Improving Citations to your Published Work. University of BATH [in English].

4. Ball, R. \& Mittermaier, B. \& Tunger, D. (2009). Creation of journal-based publication profiles of scientific institutions. A methodology for the interdisciplinary comparison of scientific research based on the J-factor. Journal of Scientometrics, 81(2), 381-392. doi:10.1007/s11192-009-2120-5 [in English].

5. Ebbs, M. (2018). 10 easy ways to increase your citation count: A checklist. Retrieved from www.aje.com/arc/10-easy-ways-increase-your-citationcount-checklistEbbs [in English].

6. Hwang, A. \& Arbaugh, J. B. \& Bento, R. F. \& Asarta, C. J. \& Fornaciari, C. J. (2019). What causes a Business and Management Education article to be cited: Article, author, or journal? The International Journal of Management Education, 17(1), 139-150. doi:10.1016/j.ijme.2019.01.005 [in English].

7. Elgendi, M. (2019). Characteristics of a highly cited article: A machine learning perspective. Journal of IEEE Access, 1-1. doi:10.1109/access. 2019.2925965 [in English].

8. Wang, M. \& Yu, G. \& An, S. \& Yu, D. (2012). Discovery of factors influencing citation impact based on a soft fuzzy rough set model. Journal of Scientometrics, 93, 635-644. doi:10.1007/s11192-012-0766-x [in English].

9. Kostoff, R. (2007). The difference between highly and poorly cited medical articles in the journal Lancet. Journal of Scientometrics, 72(3), 513-520. doi:10.1007/s11192-007-1573-7 [in English].

10. Letchford, A. \& Moat, H. \& Preis, T. (2015). The advantage of short paper titles. Journal of Roy. Soc. Open Sci., 2, 150-266 [in English].

11. Merton, R. (1968). The Matthew effect in science: The reward and communication systems of science are considered. Journal of Science, 159(3810), 56-63. doi:10.1126/science.159.3810.56 [in English].

12. Van Raan, A. (2004). Sleeping Beauties in science. Journal of Scientometrics, 59(3), 467-472. doi:10.1023/b:scie.0000018543.82441.f1 [in English].

13. Ball, P. (2011). Are scientific reputations boosted artificially? Nature. Retrieved from https://www.nature.com/news/2011/110506/full/news.2011. 270.html [in English]. 
14. Di Bitetti, M. \& Ferreras, J. (2016). Publish (in English) or perish: The effect on citation rate of using languages other than English in scientific publications. Journal of Ambio, 46(1), 121-127. doi:10.1007/s13280-016-0820-7 [in English].

15. Webster, G. \& Jonason, P. \& Schember, T. (2009). Hot topics and popular papers in evolutionary psychology: Analyses of title words and citation counts in evolution and human behavior, 1979-2008. Journal of Evol. Psychol., 7, 348-362 [in English].

16. MacCallum, C. \& Parthasarathy, H. (2006). Open Access increases citation rate. Journal of PLoS Biology, 4(5). Retrieved from https://dx.doi.org/ 10.1371/journal.pbio.0040176 [in English].

17. Jamali, H. \& Nikzad, M. (2011). Article title type and itsrelation with the number of downloads and citations. Journal of Scientometrics, 88(2), 653-661 [in English].

18. Wuchty, S. \& Jones, B. F. \& Uzzi, B. (2007). The Increasing Dominance of Teams in Production of Knowledge. Journal of Science, 316(5827), 1036-1039 [in English].

19. Ale Ebrahim, N. (2012). Publication Marketing Tools 'Enhancing Research Visibility and Improving Citations'. Journal of Research Tools in Education Series, 1(2), 1-86 [in English].

20. Ebbs, M. (2019). 10 Easy Ways to Increase Your Citation Count: $A$ Checklist. Retrieved from http://www.aje.com/arc/10-easy-ways-increaseyour-citation-count-checklist/ [in English].

21. Griffiths, M. (2015). How to improve your citation count. Journal of PsyPAG Quarterly, 96, 23-24. Retrieved from http://www.academia.edu/ 19319323/Griffiths M.D. 2015 . How to improve your citation count. PsyPAG_Quarterly_96_23-24 [in English].

\section{Статистика цитирований научных публикаций отражает} признание обнародованных научных идей, их влияние на исследования других ученых и практическую ценность научных результатов. В качестве индикатора качества статьи цитирование важно для отдельного ученого, научного коллектива, учреждения и страны в целом. В предлагаемой статье на эмпирическом материале обобщены рекомендации по повышению уровня цитирования научных публикаций.

Ключевые слова: цитируемость; количество цитирований; научный журнал; наукометрическая база; открытый доступ; обнародование научных результатов.

Statistics of citations of scientific publications reflect the recognition of published scientific ideas, their impact on researches 
of other scientists and practical value of scientific results.

As an indicator of quality article citation is important for a separate scientist, a scientific team, institutions and the country as a whole. In the proposed article on empirical material, recommendations for increasing the level of citation of scientific publications are generalized.

Keywords: citation; number of citations; scientific journal; scientometric database; open access; publication of scientific results.

Рецензент - О. В. Зоренко, канд. техн. наук, доц., КПІ ім. Ігоря Сікорського

Надійшла до редакції 21.10.19 